\title{
Uji kepekaan Staphylococcus koagulase negatif (CoNS) dari swab kloaka burung hantu asal Depok
}

\author{
Michella Hoseana Wijaya ${ }^{1}$, Usamah Afiff ${ }^{2, *}$, Aulia Andi Mustika ${ }^{3 * *}$ \\ ${ }^{1}$ Program Sarjana Fakultas Kedokteran Hewan, Institut Pertanian Bogor \\ ${ }^{2}$ Divisi Mikrobiologi Medik, Departemen Ilmu Penyakit Hewan dan Kesehatan Masyarakat Veteriner \\ Fakultas Kedokteran Hewan, Institut Pertanian Bogor \\ ${ }^{3}$ Divisi Farmakologi dan Toksikologi, Departemen Anatomi, Fisiologi dan Farmakologi, Fakultas Kedokteran Hewan, \\ Institut Pertanian Bogor
}

\begin{abstract}
ABSTRAK: Burung hantu merupakan burung pemangsa nokturnal yang saat ini banyak dijadikan hewan peliharaan di Indonesia. Namun informasi terkait penyakit dan pengobatan burung hantu masih sangat terbatas. Pengawasan penggunaan antibiotik di Indonesia juga masih lemah sehingga dapat terjadi resistensi antibiotik. Penelitian ini bertujuan mengetahui kepekaan bakteri Staphylococcus Koagulase Negatif (CoNS) dari swab kloaka satu ekor Javan owlet (Glaucidium castanopterum) dan dua ekor buffy fish owl (Ketupa ketupu) yang berasal dari penangkaran burung hantu di Depok terhadap lima jenis antibiotik menggunakan metode Kirby-Bauer. Hasil penelitian menunjukkan bakteri CoNS dari swab kloaka satu ekor javan Owlet dan satu ekor buffy fish owl resisten terhadap eritromisin, namun kedua isolat ini masih sensitif terhadap gentamisin, siprofloksasin, doksisiklin dan tetrasiklin. Untuk isolat ketiga yang berasal dari satu ekor buffy fish owl masih sensitif terhadap kelima antibiotik yang diujikan.

Kata kunci:

buffy fish owl, CoNS, javan owlet, resistensi antibiotik
\end{abstract}

\section{- PENDAHULUAN}

Burung Hantu merupakan hewan yang termasuk dalam kelompok burung pemangsa. Meskipun burung hantu tergolong sebagai hewan pemangsa, namun bentuk dan karakter setiap jenisnya yang unik dapat menarik minat banyak orang untuk menjadikan burung hantu sebagai hewan peliharaan.

Burung hantu termasuk dalam kategori hewan eksotik di Indonesia. Data dan informasi mengenai penyakit burung hantu masih sedikit sehingga kebanyakan dari pemilik burung hantu segera memberi antibiotik dengan harapan dapat menyembuhkan penyakit dari burung hantu. Penggunaan antibiotik yang tidak tepat sasaran merupakan salah satu faktor yang dapat menyebabkan resistensi antibiotik (Peterson 2005). Menurut Bari et al. (2008), kejadian resistensi merupakan penurunan atau hilangnya efektivitas obat, senyawa kimia, atau bahan lainnya yang digunakan untuk mencegah dan mengobati infeksi. Kepekaan bakteri terhadap antibiotik ditentukan oleh kadar hambat minimal dari antibiotik yang dapat menghentikan perkembangan dari bakteri tersebut. Penelitian bertujuan untuk mengetahui pola resistensi bakteri Staphylococcus Koagulase Negatif (CoNS) dari swab kloaka burung hantu.

\section{- MATERI DAN METODE}

Bahan yang digunakan berupa sampel swab kloaka dari tiga ekor burung hantu, media isolasi dan identifikasi bakteri, dan cakram antibiotik (gentamisin, eritromisin, siprofloksasin, tetrasiklin, dan doksisiklin). Sampel swab kloaka burung hantu yang diperoleh berasal dari dua ekor burung hantu jenis beluk ketupa atau buffy fish owl (Ketupa ketupu) dan satu ekor burung hantu jenis beluk watu atau Javan owlet (Glaucidium castanopterum) dari penangkaran burung hantu di Depok. Pengujian kepekaan antibiotik menggunakan metode difusi cakram menurut Kirby-Bauer. Interpretasi hasil dan penentuan kepekaan mengacu pada Clinical and Laboratory Standards Institute (CLSI) 2018.

\section{- HASIL DAN PEMBAHASAN}

Sampel swab kloaka yang diambil dari burung hantu diperoleh hasil tiga isolat bakteri CoNS. Ketiga isolat CoNS selanjutnya diuji kepekaan terhadap antibiotik menggunakan metode Kirby Bauer. Hasil uji resistensi bakteri CoNS terhadap antibiotik disajikan pada Tabel 1 .

Isolat bakteri CoNS nomor 1 yang berasal dari burung hantu jenis Javan owlet menunjukkan resistensi pada antibiotik eritromisin namun masih sensitif terhadap antibiotik siprofloksasin, doksisiklin, gentamisin, dan tetrasiklin. Isolat bakteri CoNS nomor 2 yang didapat dari satu ekor burung hantu jenis buffy fish owl menunjukkan sensitif terhadap 
semua jenis antibiotik yang diujikan. Isolat bakteri CoNS nomor 3 yang berasal dari satu ekor burung hantu jenis buffy fish owl menunjukkan hasil yang sama dengan isolat 1 .

Tabel 1 Hasil uji resistensi CoNS terhadap antibiotik

\begin{tabular}{ccccccc}
\hline \multirow{2}{*}{ Antibiotik } & \multicolumn{3}{c}{$\begin{array}{c}\text { Rataan Zona Inhibisi pada } \\
\text { Isolat (mm) }\end{array}$} & \multicolumn{4}{c}{$\begin{array}{c}\text { Jumlah } \\
\text { Isolat }\end{array}$} \\
\cline { 2 - 7 } & 1 & 2 & 3 & $\mathrm{~S}$ & $\mathrm{I}$ & $\mathrm{R}$ \\
\hline & $10,3(\mathrm{R})$ & $27,3(\mathrm{~S})$ & $8,6(\mathrm{R})$ & 1 & 0 & 2 \\
E & $26,0(\mathrm{~S})$ & $26,0(\mathrm{~S})$ & $22,0(\mathrm{~S})$ & 3 & 0 & 0 \\
CIP & $31,6(\mathrm{~S})$ & $29,0(\mathrm{~S})$ & $19,3(\mathrm{~S})$ & 3 & 0 & 0 \\
DO & $24,0(\mathrm{~S})$ & $23,6(\mathrm{~S})$ & $19,6(\mathrm{~S})$ & 3 & 0 & 0 \\
CN & $29,3(\mathrm{~S})$ & $26,3(\mathrm{~S})$ & $20,0(\mathrm{~S})$ & 3 & 0 & 0 \\
TE & &
\end{tabular}

Keterangan: CIP (Siprofloksasin), CN (Gentamisin), DO (Doksisiklin), E (Eritromisin), I (Intermediet), R (Resisten), S (Sensitif), TE (Tetrasiklin)

Staphylococcus sp. adalah bakteri yang sering ditemui pada saluran gastrointestinal (Kloos \& Bannerman 1994). Tidak semua bakteri Staphylococcus sp. bersifat patogen. Beberapa spesies dari Staphylococcus sp. merupakan bakteri flora normal pada tubuh hewan maupun manusia seperti $S$. epidermidis. Bhaiyat et al. (2013), menyatakan bahwa beberapa spesies dari CoNS bersifat patogen opportunis.

Penelitian Nielsen et al. (2018) melaporkan dari 16 burung pemangsa yang sedang dirawat di rumah sakit hewan Portugal ditemukan isolat CoNS dari nasofaring yang resisten terhadap beberapa antibiotik salah satunya yaitu eritromisin. Hasil uji resistensi CoNS terhadap eritromisin menunjukkan hasil yang berbeda antara isolat 2 dan 3 yang berasal burung hantu dengan spesies yang sama dan diberi makanan yang sama yaitu ikan lele dan DOC. Kemungkinan perbedaan pola resistensi terjadi akibat perbedaan spesies pada kedua CoNS yang ditemukan disebabkan pengujian yang dilakukan dalam mengidentifikasi bakteri tidak sampai pada tingkat spesies.

\section{- SIMPULAN}

Hasil uji resistensi isolat CoNS menunjukkan bahwa dua dari tiga isolat dalam penelitian ini telah resisten terhadap eritromisin. Antibiotik yang masih sensitif digunakan untuk mengobati ketiga burung hantu yang dikoleksi isolat swab kloaka yaitu gentamisin, siprofloksasin, doksisiklin dan tetrasiklin.

\section{INFORMASI PENULIS}

Penulis Korespondensi

*UA: uafifff60@gmail.com

Divisi Mikrobiologi Medik, Departemen Ilmu Penyakit Hewan dan Kesehatan Masyarakat Veteriner, Fakultas Kedokteran Hewan, Institut Pertanian Bogor.

Jl. Agatis Kampus IPB Dramaga Bogor 16680

**AAM: auliaandi@apps.ipb.ac.id

Divisi Farmakologi dan Toksikologi, Departemen Anatomi, Fisiologi dan Farmakologi, Fakultas Kedokteran Hewan, Institut Pertanian Bogor.

Jl. Agatis Kampus IPB Dramaga Bogor 16680.

\section{- PUSTAKA ACUAN}

Bari SB, Mahajan BM, Surana SJ. 2008. Resistance to Antibiotic: A Challenge in Chemotheraphy. Indian Journal of Pharmaceutical Education and Research. 42(1): 3-11.

Bhaiyat MI, Hariharan H, Chikweto A, Tiwari K, Sharma RN, Kobayashi Y. 2013. Isolation of Coagulase-Negative Staphylococcus sp. and Kocuria Varians in Pure Culture from Tissues of Cases of Mortalities in Parrots in Grenada, West Indies. International Journal of Veterinary Medicine: Research \& Reports. 2013:1-6

[CLSI] Clinical and Laboratory Standards Institute. 2018 Performance Standards for Antimicrobial Suspentibility Testing; Twenty-Eight Informational Supplement. Wayne (US): CLSI.

Kloos WE, Bannerman TL. 1994. Update on Clinical Significance of Coagulase-Negative Staphylococci. Clinical Microbiology Reviews. $7(1): 117-140$

Nielsen KM, Gjøen T, Asare NY, Lunestad BT, Ytrehus B, Yazdankhah SP, Godfroid J, Jelmert A, Klein J, Okoli AS, Tronsmo A. 2018. Antimicrobial Resistance in Wildlife-Potential for Dissemination. Oslo: Norwegian Scientific Committee for Food and Environment (VKM).

Peterson LR. 2005. Squeezing the antibiotic balloon: the impact of antimicrobial classes on emerging resistance. Clinical Microbiology and Infection. 11(2005):4-16. 